\title{
THE ROLE OF THE LAW REVIEW: A SElect Bibliography*
}

\section{TABLE OF CONTENTS}

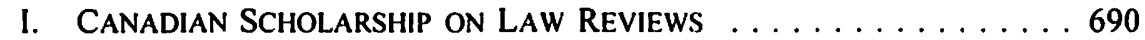

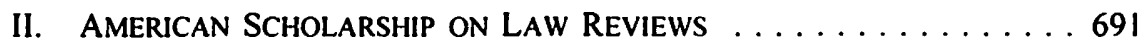

III. FOREIGN SCHOLARSHIP ON LAW REVIEWS $\ldots \ldots \ldots \ldots \ldots \ldots 693$

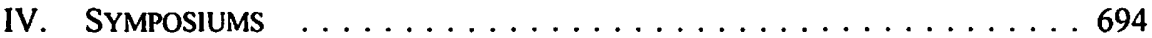

V. HUMOUROUS ARTICLES $\ldots \ldots \ldots \ldots \ldots \ldots \ldots \ldots \ldots$

\section{CANAdian SChOlarshiP}

Bale, G., "W.R. Lederman and the Citation of Legal Periodicals in the Supreme Court of Canada" (1994) 19 Queen's L.J. 36.

Bastarache, M., "The Role of Academics and Legal Theory in Judicial Decision-Making" (1999) 37 Alta. L. Rev. 739.

Bowker, W.F.,"Extra-Judicial Writing: The Alberta Law Quarterly and the Alberta Law Review in Particular and Texts and Reviews in General" (1980) 18 Alta. L. Rev. 458.

Burns, P. et al., “A Noteworthy Review” (1999) 33 U.B.C. L. Rev. 3.

Curtis, G., "Fifty Years On" (1999) 33 U.B.C. L. Rev. 1.

Lackman, J., "Afterword: Forty Years Later" (1995) 40 McGill L.J. 1025.

MacDonald, R.A., "Understanding Civil Law Scholarship in Quebec"(1985) 23 Osgoode Hall L.J. 573.

MacLaren, M., "A History of the University of Toronto Faculty of Law Review" (1997) 55 U.T. Fac. L. Rev. 375.

Mewett, A.W., "Reviewing the Law Reviews" (1955) 8 J. Leg. Ed. 188.

Nicholls, G.V.V., "Legal Periodicals and the Supreme Court of Canada" (1950) 28 Can. Bar Rev. 422.

Normand, S., "Profil des periodiques juridiques quebecois aux XIXe siecle"(1993) 34 C. de D. 153.

Normand, S., "Un theme dominant de la pensee juridique traditionelle au Quebec: La sauvegarde de l'integrite du droit civil" (1987) 32 McGill L.J. 559. 
Normand, S., "Une analyse qualitative de la doctrine en droit civil quebecois" (1982) 23 C. de D. 153.

Risk, R.C.B., "Volume I of the Journal: A Tribute and Belated Review" (1987) 37 U.T.L.J. 193.

Smith, A., "The Alberta Law Quarterly: Random Reminiscences" (1980) Twenty-Fifth Anniversary Issue Alta. L. Rev. 38.

Stevenson, W.A., "The 'Emergence' of the Alberta Law Review" (1980) Twenty-Fifth Anniversary Issue Alta. L. Rev. 45.

Vaughan, B. \& Richter, N., "Did She Mention My Name?: Citation of Academic Authority by the Supreme Court of Canada" (1993) 16 Dal. L.J. 377.

\section{AMERICAN SCHOLARSHIP}

Archer, J.D., "The Importance of Law Reviews to the Judiciary and the Bar" (1991) Det. Coll. L. R. 229.

Bryden, D.P., "Scholarship about Scholarship" (1992) 63 U. Col. L. Rev. 641.

Cramton, R.C., "The Most Remarkable Institution: The American Law Review" (1986) 36 J. Leg. Ed. 1.

Denemark, H.A., "How Valid is the Oft-Repeated Accusation That There Are Too Many Legal Articles and Too Many Law Reviews?" (1996) 30 Akron L. Rev. 215.

Denemark, H.A., "The Death of the Law Reviews has been Predicted: What Might be Lost When the Last Law Reviews Shuts Down" (1996) Seton Hall L. Rev. 1.

Edwards, H.T., "The Growing Disjuncture Between Legal Education and the Legal Profession" (1992) 91 Mich. L. Rev. 34.

Edwards, H.T., "The Growing Disjunction Between Legal Education and the Legal Profession: A Postscript" (1993) 91 Mich. L. Rev. 2191.

Edwards, H.T., "Another Postscript to the Growing Disjunction Between Legal Education and the Legal Profession" (1994) 69 Wash. L. Rev. 561.

Friedman, L.M., "Law Reviews and Legal Scholarship" (1998) 75 Neb. L. R. 661.

Fuld, S.H., “A Judge Looks at the Law Reviews" (1953) 28 N.Y.U. L. Rev. 915.

Harnsberger, R.S., "Reflections About Law Reviews and American Legal Scholarship" (1997) 76 Neb. L. R. 681. 
Harper, J.W., “Why Student-Run Law Reviews?" (1998) 82 Minn. L. Rev. 1261.

Havinghurst, H.C., "Law Reviews and Legal Education" (1956) 51 Nw. L. Rev. 22.

Hibbitts, B.J., "Last Writes? Re-assessing the Law Review in the Age of Cyberspace" (1996) 71 N.Y.U. L. Rev. 615.

Hibbitts, B.J., "Yesterday Once More: skeptics, scribes and the demise of the law reviews" (1996) 30 Akron L. Rev. 267.

Jensen, E.M., "Law Review Correspondence: Better Read than Dead?"(1991-92) 24 Con. L. Rev. 159.

Kaye, J.S., "One Judge's View of Academic Law Review Writing" (1989) 39 J. Leg. Ed. 440.

Kozinski, A., "Who Gives a Hoot About Legal Scholarship?" (2000) 37 Houston L. Rev. 295.

Lasson, K., "On Letters \& Law Reviews: A Jaded Rejoinder" (1991-92) 24 Conn. L. Rev. 159.

Lindgren, J., "Reforming the American Law Review" (1995) 47 Stan. L. Rev. 1123.

Maggs, D.B., "Concerning the Extent to Which the Law Review Contributed to the Development of the Law" (1930) 3 S. Cal. L. Rev. 181.

Martin, S.M., "The Law Review Citadel: Rodell Revisited"(1986) 71 lowa L. Rev. 1093. Martinez, L.P., "Babies, Bathwater, and Law Reviews" (1995) 47 Stan. L. Rev. 1139. Maru, O., "Measuring the Impact of Legal Periodicals"(1976) Am. B. Found. Res. J. 227. McDowell, B., "The Audience for Legal Scholarship" (1990) 40 J. Leg. Ed. 261.

Noonan, J.T., "Law Reviews" (1995) 47 Stan. L. Rev. 1117.

Perritt, H.H.Jr., "Reassessing Professor Hibbitts's Requiem for Law Reviews" (1996) 30 Akron L. Rev. 255.

Posner, R.A., "The Future of Student-Edited Law Review" (1995) 47 Stan. L. Rev. 1131.

Rains, R.E., “Andrea's Adventures in Law Review Land” (2000) 50 J. Leg. Ed. 306.

Rier, D.A., "The Future of Legal Scholarship and Scholarly Communication: Publication in the Age of Cyberspace" (1996) 30 Akron L. Rev. 183. 
Rodell, F., "Goodbye to Law Reviews" (1936) 23 Va. L. Rev. 38.

Rodell, F., "Goodbye to Law Reviews-Revisited" (1962) 48 Va. L. Rev. 279.

Rosencrantz, E.J., "Law Review’s Empire" (1988) 39 Hastings L.J. 859.

Rotunda, R.D., "Law Reviews: The Extreme Centrist Position" (1986-87) 62 In. L.J. I.

Saks, M.J., Larsen, H., \& Hodne, C.J., "Is There a Growing Gap Among Law, Legal Practice, and Legal Scholarship?: A Systematic Comparison of Law Review Articles One Generation Apart" (1996) 30 Suffolk U.L. Rev. 353.

Saunders, N.H., "Student-Edited Law Reviews: Reflections and Responses of an Inmate" (2000) 49 Duke L.J. 1663.

Schlegal, J.H., “An Endangered Species?”(1986) 36 J. Leg. Ed. 18.

Shapiro, C., "The Most-Cited Legal Books Published Since 1978" (2000) 29 J. Leg. Stud. 397.

Shapiro, C., "The Most-Cited Law Review Articles" (1985) 73 Cal. L. Rev. 1540.

Sirico, L.J.Jr., "The Citing of Law Reviews by the Supreme Court: 1971-1999" (2000) 37 In. L.J. 1009.

Stein, P., "Law Reviews and Legal Culture" (1996) 70 Tulane L. Rev. 2675.

Steir, M. et al., "Law Review Usage and Suggestions for Improvement: A Survey of Attorneys, Professors and Judges" (1992) 44 Stan. L. Rev. 1467.

Weisberg, R., "Some Ways to Think About Law Reviews"(1995) 47 Stan. L. Rev. 1147.

Westwood, H., "The Law Review Should Become the Law School"(1945) 31 Va. L. Rev. 913.

Zimmerman, R., "Law Reviews: A Foray Through a Strange World"(1998) 75 Den. U.L. Rev. 661.

\section{FOREIGN SCHOLARSHIP}

Gava, J., "Commentary on Goodbye to Law Reviews" (1991) 7 Aust. J. L. \& Soc. 106.

Smyth, R., "Academic Writing and the Courts" (1999) 17 U. Tas. L. Rev. 164.

Smyth, R., "What Do Intermediate Appellate Courts Cite?" (1999) Adel. L. Rev. 51.

Smyth, R., "The Authority of Secondary Authority" (1999) 9 Griffith L. Rev. 25. 


\section{SYMPOSIUMS}

"Student Edited Law Reviews" (1986) 36 J. Leg. Ed. 1.

“A Symposium on Legal Scholarship" (1992) 63 U. Colo. L. Rev. 521.

"Nova, Humor in the Law Review" (1993) 17 Nova L. Rev. 664.

Lindgren, J. ed., "Symposium on Law Review Editing: The Struggle Between Author and Editor over the Control of the Text" (1994) 70 Chi.-Kent L. Rev. 71.

“Special Issue: Law Review Conference" (1995) 47 Stan. L. Rev. 1117.

"Special Issue: Who Needs Law Reviews? Legal Scholarship in the Age of Cyberspace" (1996) 30 Akron L. Rev. 173.

“Interpreting Legal Citations" (2000) 29 J. Leg. Stud. 1.

\section{Humourous Articles}

Jensen, E.M., "Comments in Reply" (2000) 50 J. Leg. Ed. 312.

Morris, G.H., "The Shortest Article in Law Review History: A Brief Response to Professor Jensen" (2000) 50 J. Leg. Ed. 310.

Nowak, J.E., “Woe Unto You, Law Reviews!" (1985) 27 Ariz. L. Rev. 317.

Odom, T.H., “A Response to Professors Jensen and Morris" (2000) 50 J. Leg. Ed. 311. 